CLINICAL HEMORHEOLOGY, Vo1. 1, pp. 215-216, 1981

0271-5198/81/020215-02\$02.00/0 Printed in the USA.

Copyright (c) 1981 Pergamon Press Ltd. All rights reserved.

\title{
ANNOUNCEMENTS
}

\section{THE FOURTH INTERNATIONAL CONGRESS OF BIORHEOLOGY}

Tokyo, Japan. 27. July to 1. August 1981

The Fourth International Congress of Biorheology will be held in Tokyo, Japan from July 27 to August 1, 1981 at Jikei University School of Medicine. The Congress language is English. Correspondence should be directed to:

Professor Y. Matunobu, Secretary General

The Fourth International Congress of Biorheology

Department of Physics, Keio University

Hiyoshi, Kohoku-ku, Yokohama 223

JAPAN

Abstracts and Papers on clinical hemorheology presented at this Congress will be published in CLINICAL HEMORHEOLOGY. The Editors-in-Chief believe that many Readers of this journal will be interested in participating in the Congress as many Papers on hemorheology including clinical hemorheology will be presented. New information about the Congress will be published in the forthcoming issue of CLINICAL HEMORHEOLOGY.

International Symposium on HEMORHEOLOGICAL APPROACH TO CARDIOVASCULAR DISEASES

A Satellite Meeting of the Fourth International Congress of Biorheology

Osaka, Japan. August 3, 1981.

A satellite symposium on Hemorheological Approach to Cardiovascular Diseases (ISHA) will be held on August 3 (Monday) at National Cardiovascular Center, Osaka. The scientific program will include three invited lectures and a symposium on Contribution of Hemorheology to Clinical Medicine. All correspondence concerning the Symposium should be sent to Dr. Hideyuki Niimi, Secretary General ISHA, National Cardiovascular Center, 5-125 Fujishiro-dai, Suita, Osaka 565, Japan. 


\section{SECOND EUROPEAN CONFERENCE ON}

\section{CLINICAL HEMORHEOLOGY}

London, England. 30. September - 2. October, 1981

The principal aim of this conference will be to encourage further links between the rapidly expanding science of haemorheology and the clinical practice of medicine and surgery. Sessions will be primarily arranged around individual disease processes such as diabetes, cerebrovascular disorders, myocardial and limb ischaemia. There will also be sessions on methodology and therapy as well as other clinical topics of haemorheology interest.

An exciting social and ladies' programme is being arranged for the participants of the conference.

If you would like further details, please write to:

Miss B. Komoniewska BA, Conference Secretary

Second European Conference on Clinical Haemorheology

Royal Society of Medicine

1. Wimpole Street, London WIM 8AE, United Kingdom

President of the Conference: Sir John Stallworthy

Vice Presidents: A.L. Copley, G.W. Scott Blair

Organising and Scientific Advisory Committees: J.A. Dormandy

(Chairman), P.T. Flute (Vice Chairman), A.J. Barnes (Programme Secretary), J.R. Pattison (Treasurer), B. Komoniewska (Conference Secretary), G. Bennette, A. Bloom, G.V.R. Born, N.L. Browse, C.G. Caro, S. Chien, N. Cristal, T. di Perri, J. Ditzel, L. Dintenfass, P. Drouin, A. Ehrly, C. Forbes, S. Forconi, E. Fukada, P. Gaehtgens, C. George, M. Hanss, H. Hartert, G. Holti, E. Housley, E. Housset, Irene Juhan, Z.S. Latallo, P. Leblond, G. Lowe, G.A. Marcel, J. Marshall, H. Meiselman, T.C. Pearson, M. Samama, H. SchmidSchbnbein, G.V.F. Seaman, A. Silberberg, J. Sirs, J.F. Stoltz, J. Stuart, D.J. Thomas, D.P. Thomas, M. Verstraete.

\section{WORKING GROUP ON RED CELL DEFORMABILITY AND FILTERABILITY}

\section{London, UK. 29. September, 1981.}

A working group meeting on Methods for the Measurement of Red Cell Deformability and Filterability has been scheduled to take place on September 29, 1981 one day prior to the Second European Conference on Clinical Hemorheology. Any information pertaining to this meeting may be obtained from Dr. G.D.O. Lowe, University of Glasgow, Department of Medicine, Royal Infirmary, 86 Castle st., Glasgow, G4 OSF, UK. Telephone Number: (041) 552-3535. 